\title{
LHX2 wt Allele
}

National Cancer Institute

\section{Source}

National Cancer Institute. LHX2 wt Allele. NCI Thesaurus. Code C53013.

Human LHX2 wild-type allele is located within 9q33-34.1 and is approximately $22 \mathrm{~kb}$ in length. This allele, which encodes the LIM/homeobox protein Lhx2, may play a role in both the modulation of transcription by RNA polymerase II and the development of lymphoid and neural cells. 